\title{
The Law and Practice of Government Shutdowns in the United States
}

\begin{abstract}
This article analyzes the legal rules governing operations of the federal government of the United States during lapses of appropriations (commonly known as government shutdowns). After briefly explaining what government shutdowns are and when they happen, it presents the main sources of the applicable law, starting with its statutory basis - the Antideficiency Act. After analyzing the history, purpose, and text of that statute, the article presents two official opinions of the Attorney General which interpreted the Act to require suspension of non-essential government operations during funding gaps. The article then proceeds to delineate statutory and implied exceptions to that requirement. Its second part consists of an analysis of actual administration practice during shutdowns. On the basis of agency contingency plans posted during the 2013 shutdown, it identifies the government activities that continued despite the shutdown, and briefly describes each activity's scale and the legal basis for it being exempt from the generally applicable rules. It concludes that while there have been disputes about the administration's handling of the shutdown, the agency's practice was generally consistent with the legal rules, though the statutory framework itself would benefit from congressional revision and clarification.
\end{abstract}

In October 2013, a dispute over de-funding the 2010 health insurance reform, the last in a string of budgetary controversies arising since the 2008 financial crisis, prevented enactment of both regular appropriations and interim budgetary measures, leading to a lapse of the United States government's funding and causing a two-week-long 'government shutdown,' a suspension of most of the federal government's programs and activities. Budgetary deadlocks like the one described here are by themselves unusual in highly developed countries, and the American response to them - suspension of affected government activities - is unique among modern countries (Williams, Jubb 471). While such suspensions are rare (the 2013 shutdown was the first one since 1995, and also the second ever to last over one week), there already exists a complex set of legal rules governing them. The purpose of this article is to analyze those rules and compare them with political practice during the recent shutdowns (especially the one in 2013). 


\section{The Appropriations Clause and the power of the purse}

It is one of the foundational principles of the American constitutional order that the legislative branch, and it alone, holds "the power of the purse" (Stith, "Congress' Power of the Purse" 1344-1346; Małajny, Amerykański prezydencjalizm 107-135), i.e. exclusive power to raise revenue, borrow money and authorize public expenditures (Małajny, Pozycja ustrojowa Kongresu USA 1: 115-139). James Madison has described congressional control over government spending as "the most complete and effectual weapon with which any constitution can arm the immediate representatives of the people, for obtaining a redress of every grievance, and for carrying into effect every just and salutary measure" (Madison, The Federalist No. 58 303), and the power of the purse has proved to be one of the most important congressional checks over the executive branch (see, e.g.: Raven-Hansen and Banks, "Pulling the Purse Strings of the Commander in Chief").

The constitutional foundation of the power of the purse may be found in the Appropriations Clause of the U.S. Constitution (Art. I, § 9, cl. 7), providing that "[n]o money shall be drawn from the treasury, but in consequence of appropriations made by law." Accordingly, no governmental expenditures may be made without congressional authority, which may be provided either by permanent legislation or by more usual periodic appropriation acts. ${ }^{1}$ Permanent appropriations now account for a majority of government outlays. Classic justification for their use was to pay binding obligations of the government, such as interest on the public debt (31 U.S.C. $\S 1305(2)$ ), salvage fees in admiralty cases (§ 1305(3)), judgments and arbitral awards against the United States (\$1304), refunds of taxes erroneously or illegally collected (§ 1322(b)(2)), or congressional compensation (Pub. L. 97-51, § 130(c), 95 Stat. 966, 2 U.S.C. $\S 31$ note).

Permanent appropriations are now used primarily to exempt entitlement programs, such as Social Security payments from the Social Security Trust Funds (42 U.S.C. § 401) and Medicare payments from the Federal Hospital Insurance Trust Fund (42 U.S.C. § 1395a), from annual reevaluation. ${ }^{2}$ Other examples of permanent spending authority include "offsetting collections" authority (authority to fund ongoing operations from fees or similar receipts without paying them into the Treasury) ("Budget Concepts" 126) ${ }^{3}$ and "no-year definite appropriations" - appropriations that are available until expended without any fiscal year limitation. ${ }^{4}$

1 There is no constitutional requirement that appropriations be annual, though such has been the uniform practice of the government since 1789 (Schick 215). However, appropriations for the support of the Army are constitutionally limited to two years' duration.

2 It should be noted that the permanent appropriations for Social Security and Medicare are limited to the balance of their respective trust funds. Should they be exhausted, there is no legal authority to supplement them from the general funds in the Treasury without additional legislation. For a more detailed discussion, see Moore (43-52).

3 Examples include mail service and proprietary revenues of the Postal Service (39 U.S.C. § 2003), proceeds from foreign military sales under the Military Assistance Program (22 U.S.C. § 2344), and Medicare premiums (42 U.S.C. § 1395i-2). See: “Offsetting Collections and Offsetting Receipts" 219-239.

4 Permanent appropriations should not be mistaken with "mandatory spending" (also known as direct spending), a term introduced in the Budget Enforcement Act (Pub. 
Unfortunately, there is no up-to-date catalog of permanent appropriations (a 1996 General Accounting Office report (General Accounting Office. Inventory of Accounts With Spending Authority and Permanent Appropriations, GAO/AIMD-96-79, B-260063) and its General Accounting Office, "Inventory of Accounts With Spending Authority and Permanent Appropriations (1997 Supplement)," OGC-98-23, B-266063 1997 supplement are the most recent sources).

While permanent appropriations account for a larger share of the federal budget than ever before, most government activities are still funded by annual appropriations. They account for virtually all national defense spending, several entitlement programs (most notably Medicaid), infrastructural expenditures, research and development, education and other grants to states, and current operating expenses of most government agencies (Oleszek 44). Ordinary practice is to group annual appropriations into a number of appropriation acts - currently twelve (House Practice... \& 4:6 p. 76) - but in recent decades this rule has been honored more in the breach than in the observance, as Congress frequently resorted to enacting large, 'omnibus' acts, replacing some (or even all) of the ordinary funding bills (Schick 260-262; Krutz 68; Tollestrup, "Omnibus Appropriations Acts...").

Funding the government through annual measures always involves a risk of a 'funding gap' - failure to enact them before the start of the new fiscal year. Appropriations are among the most important items of legislation, and even in times of relative political tranquility involve fierce competition among interest groups and political actors for access to public funding (Rubin 30; Schick 2-4). Decentralization of budgetary decision-making in Congress and relatively weak party discipline produce a high risk of delays, which can be further magnified by a divided government (Woon, Anderson 424-427). According to Congressional Research Service, all regular appropriation acts have been enacted on time only four times since 1952 (Tollestrup, "Federal Funding Gaps..." 4; see also: Woon, Anderson 423-424, Seam, Shron 3).

Failure to enact regular appropriations on time, however, does not necessarily lead to a government shutdown. Usually, such a case is dealt with by enacting a continuing resolution - a joint resolution that provides interim budget authority for unfunded agencies to keep them operating (Oleszek 61; Tollestrup, "Continuing Resolutions..." 1-2 and passim; Devins 392-396). Traditionally, continuing resolutions were mostly short and uncontroversial, limiting themselves to providing interim budget authority and restraining agencies from engaging in new initiatives or otherwise prejudicing congressional ability to shape pending appropriation bills

L. No. 101-508, Title XIII, § 13101(a), 104 Stat. 1388-573) to describe expenditures that are not freely set for each fiscal year, but predetermined by existing legislation (mostly entitlements) ("Budget Concepts" 129, 138; Fay, Rodgers 3-4). As of 2008, only about $62 \%$ of mandatory spending was funded through permanent appropriations (Fay and Rodgers 2). Nor should either of those two concepts be mistaken with binding obligations of the United States. Only a few spending items are truly binding upon the government (i.e. immune to statutory cuts): public debt, compensation of the President, judges and members of Congress, judgments against the United States (cf. Plaut v. Spendthrift Farm, Inc, 514 U.S. 211, 218-219 (1995)), and contractual obligations. Entitlements, such as Social Security benefits, do not represent a "vested right," but only a moral obligation, so they may (in theory) be reduced, altered, or taken away by Congress (Flemming v. Nestor, 363 U.S. 603 (1960)). 
(Schick 260, 262), though in recent decades they have grown to deal with an increasing number of policy issues (Devins 392-394).

Sometimes, however, Congress and the President are unable to agree even on the continuing resolution. This has become a more frequent occurrence since the 1960s, due to increasing political conflict over budgetary issues (Williams, Jubb 474) and transformation of continuing resolutions into complex vehicles for policy issues (Seam, Shron 4; General Accounting Office. Funding Gaps Jeopardize Federal Government Operations, B-197841 8-12), sometimes replacing regular appropriation bills altogether. If no continuing resolution is passed before previous funding expires, budgetary authority for relevant programs and agencies lapses, and at this point the legal framework that is the subject of this article comes into play.

\section{Statutory framework - the Antideficiency Act}

The starting point in the analysis of the law of government shutdown is, of course, the Appropriations Clause. The language of the clause is clear and admits no exception - no money shall be drawn from the Treasury in the absence of appropriations. But it is not fully self-executing (Stith, "Rewriting the Fiscal Constitution..." 600), and agencies have developed a number of devices for avoiding congressional restrictions on expenditures. One of the major challenges to effective congressional control over appropriations have been deficiencies, i.e. circumstances de facto forcing Congress to appropriate additional funds beyond original appropriation acts. While some deficiencies have resulted from truly unforeseen circumstances, of more concern to the legislative branch have been "coercive deficiencies," arising from conscious actions by bureaus and agencies (e.g. obligations contracted either in excess or in advance of appropriations ${ }^{5}$ ). Such deficiencies have caused the legislative branch to develop a complex statutory framework, known as the Antideficiency Act, to maintain its control over public expenditures.

\subsection{Origins and history of the Antideficiency Act}

Initially, deficiencies were incurred primarily during lapses of appropriations (it was usual at the time for regular appropriations acts to be passed well into the year for which they applied) (Wilmerding 26) or in response to urgent contingencies (e.g. during the Whiskey Rebellion) (Casper 16). In all such cases, such expenditures were followed with requests for supplemental appropriations (Casper 12; Hamilton 464). Deficiencies also occurred when agency spending exceeded estimates transmitted by the Treasury to Congress (see, e.g.: Wilmerding 45).

These early fiscal practices of the Treasury Department were a subject of major political controversy between the Federalists, who defended Secretary Alexander

5 Some agencies found creative ways to pay the deficiency obligations while still following the letter of the Appropriations Clause. One way to do so was to "borrow" funds from the surplus in another appropriation account (Wilmerding 103-104) or to permit disbursing officers to intermingle funds from different accounts (White, The Jeffersonians... 116). Another one was for the Secretary of the Treasury to request informal advances by the depositary banks with the understanding that the sums would be reimbursed from new appropriations (Baldwin 116-117). 
Hamilton, and the Republicans, led by Albert Gallatin, who argued for greater congressional control (see: Casper 12-18; Currie 66; White, The Federalists... 323-334). When the latter came into power in 1801, they proceeded to put their ideas about sound financial management into practice, introducing line-item appropriations and restricting inter-appropriation transfers (White, The Jeffersonians... 109-115; see also: Act of March 3, 1809, c. 28, 2 Stat. 535). But with greater particularization, errors in the estimates and unexpected contingencies came up more often, and deficiency obligations became an attractive way to evade the new restrictions (White, The Jeffersonians... 115-116; White, The Jacksonians... 135-137). In response, in 1820 Congress enacted the first antideficiency legislation: a statute forbidding executive departments to enter into any contract "except under a law authorizing the same, or under an appropriation adequate to its fulfillment" (Act of May 1, 1820, c. 52, § 6, 3 Stat. 567, 568). ${ }^{6}$

The administrative expenditures control system established in the first half of the nineteenth century completely broke down during the Civil War (White, The Republican Era... 58). While some of the war-time deficiencies were justified by emergency circumstances ${ }^{7}$, many were caused by general relaxation in congressional control resulting from unprecedented increase in government expenditures (Wilmerding 116-117). After the war, Congress sought to reassert its authority by a series of statutes curtailing executive discretion in budget execution (White, The Republican Era... 58-59): banning inter-appropriation transfers (Act of Feb. 12, 1868, c. 8, § 2, 15 Stat. 35, 36), extinguishing unexpended balances (Act of Jul. 12, 1870, c. 251, § 5, 16 Stat. 230, 251), and prohibiting agencies from making expenditures or contracts in excess of appropriations (Act of Jul. 12, 1870, c. 251, § 7, 16 Stat. 230, 251). The last statute, later codified as section 3679 of the Revised Statutes, became the forerunner of the modern-day Antideficiency Act.

In response to congressional action, agencies turned towards other devices for evading limits on their expenditures, such as spending all funds within the first few months and requesting a supplemental appropriation. Congress had little choice but to accede, as the alternative would be to shut down the agency operations for the remainder of the fiscal year (Wilmerding 137-139; S. Doc. No. 87-11 45-46). ${ }^{8}$ Widespread evasion of the antideficiency provisions of the 1870 act finally resulted in congressional action: in 1905, Congress enacted a comprehensive amendment to section 3679, extending its scope to all government obligations (the 1870 language referred only to contracts), introducing the system of apportionment of appropriated

6 The statute did not apply to contracts for military and naval subsistence and supplies. It remains in force today (with several amendments), codified as 41 U.S.C. § 11.

7 For instance, in the first months of the war, President Lincoln authorized the War Department to spend over two million dollars of non-appropriated funds, justifying his action by the grave and immediate threat to the Union (Stith, "Congress' Power of the Purse" 1351 fn. 35). His action was later ratified by Congress (Ratification Act of 1861, c. 63, § 3, 12 Stat. 326).

One of the most notable instances of this kind of deficiency occurred in December 1879, when the Post Office Department made a request for a deficiency appropriation of $\$ 1,700,000$, explaining that otherwise it would exhaust its funding three months before the close of the fiscal year and cease to deliver the mail. While Congress was very critical of the Department's action, it enacted the appropriation (White, The Republican Era... 59-60). 
funds in monthly allotments, and establishing criminal penalties for violations (Act of Mar. 3, 1905, c. 1484, § 4, 33 Stat. 1214, 1257). In 1906, Congress strengthened the new law by restricting the ability of agencies to reapportion funds absent unforeseen contingencies (Act of Feb. 27, 1906, c. 510, § 3, 34 Stat. 27, 48; see also: Fisher 28).

The 1905 and 1906 amendments to section 3679 continue in force as the core of the Antideficiency Act. The apportionment procedures underwent a number of amendments in the 1950s (S. Doc. No. 87-11 46), including a major revision in 1950 (General Appropriation Act, 1951, c. 896, § 1211, 64 Stat. 595, 765), but none of them modified the basic principles of the statutory scheme. Nor did the 1974 changes brought about by the enactment of the Impoundment Control Act (Pub. L. No. 93-344, Title X, 88 Stat. 297, 332). The prohibition on obligations in excess or in advance of appropriations was amended only once, in 1990 (by the Budget Enforcement Act, Pub. L. No. 101-508, Title XIII, § 13213(a), 104 Stat. 1388-573, 621), to cover expenditures and obligations in violation of sequestration provisions of the Gramm-Rudman-Hollings Deficit Control Act of 1985 (Pub. L. No. 99-177, Title II, 99 Stat. 1038). The last amendment to the Act (as of April 2014) came in 2004, when Congress instituted a requirement to report violations to the Comptroller General (in addition to an earlier requirement to report to Congress and the President) (Pub. L. No. 108-447, div. G, Title I, § 1401(a), 118 Stat. 2809, 3192).

\subsection{Principal provisions}

The core of the modern Antideficiency Act is 31 U.S.C. § 1341, which prohibits government officers and employees from expending or obligating any funds in advance of appropriation or in excess of the amount available for obligation under the applicable appropriation act ${ }^{9}$ (subsec. (a)(1)(A) and (B)). Similarly, it prohibits expenditures or obligations of funds sequestered under the Gramm-Rudman-Hollings Act (subsec. (a)(1)(C) and (D))..$^{10}$ These prima facie simple prohibitions grew into a complex body of law, developed primarily through decisions and advisory opinions of the Government Accounting Office and its predecessor, the Office of the Comptroller of the Treasury (for more information, see Principles of Federal Appropriations Law 2:6-34 et seq.).

The second major component of the Antideficiency Act is 31 U.S.C. § 1342, prohibiting the government from accepting voluntary personal services (or employing

9 Ceilings stated only in committee and conference reports or in agency-submitted budget justifications are not binding on the agencies unless incorporated into the statutory text (United Automobile Workers v. Donovan, 746 F.2d 855, 860-861 (D.C. Cir. 1984); In re LTV Aerospace Corporation, 55 Comp. Gen. 307, 318-325 (GAO 1975); Stith, "Rewriting the Fiscal Constitution" 613-614), though in practice agencies tend to abide by them, if only to maintain good relations with congressional committees and subcommittees and thereby preserve flexibility associated with lump sum appropriations. Still, an expenditure or obligation in excess of those limits, however unjustified it may be deemed by the relevant committees, does not have the legal consequences of violating the Antideficiency Act (In re Newport News Shipbuilding Co., 55 Comp. Gen. 812 (GAO 1976)).

10 While the sequestration provisions of the original Gramm-Rudman-Hollings Act expired in 2002, the Budget Control Act of 2011 (Pub. L. No. 112-25, 125 Stat. 240) sequestration provisions are framed as an amendment to section 251 of the Gramm-Rudman-Hollings Act, hence they too are enforceable under the Antideficiency Act. 
paid personal services beyond the extent authorized by law). This prohibition responds to one of the earliest schemes for evading the Act: agency or bureau heads would accept "volunteer" services (usually by pressuring employees to work overtime without compensation) and then present to Congress a claim for compensation, founded on a "moral obligation" of the United States (Principles of Federal Appropriations Law 6-94 - 6-95). In 1884, this practice was prohibited by a rider to the Indian Office appropriations bill (Act of May 1, 1884, ch. 37, 23 Stat. 17), but it is unclear whether that provision applied only to the Indian Office (as held by the Court of Claims, see Glavey v. United States, 35 Ct. Cl. 242 (1900)) or to the government as a whole (as held by the Comptroller of the Treasury, see Tax on Property of the Government, 9 Comp. Dec. 181, 182 (Comp. Treas. 1902)). In 1905, the prohibition was reenacted as a part of the new Antideficiency Act in order to clarify that it was binding on all government agencies.

While on the surface section 1342 appears to bar the government from accepting any kind of services without some valuable consideration (absent some statutory exception), a number of legal opinions (see: Wickersham 51; Ulman, "Employment of Temporary..." 80-81; Carvin 1; Voluntary Services - Deputy Collector of Internal Revenue, 27 Comp. Dec. 131 (Comp. Treas. 1920)) introduced a distinction between "voluntary services," subject to the statutory prohibition, and "gratuitous services," which involve an express waiver of remuneration and may be accepted without violating the act (since they present no risk of a coercive deficiency). Such a waiver, however, cannot be made when Congress has fixed official compensation by law (or established a statutory minimum) - as in the case of employees in the civil service (Glavey v. United States, 182 U.S. 595 (1901); MacMath v. United States, 248 U.S. 151 (1918); Saltzman v. United States, 161 Ct. Cl. 634 (1963); Civilian Personnel Law Manual 2-15).

The third major component of the Antideficiency Act is subchapter II of 31 U.S.C. chapter 15 (§§ 1511-1519), dealing with apportionment of appropriations. The system of apportionment is the most complex portion of the Act, but will be only cursorily dealt with here, as it has little impact on government shutdowns. At the heart of subchapter II is section 1512, which requires most fixed-period appropriations to be apportioned by "months, calendar quarters, operating seasons, or other time periods," or by programs or activities. It also authorizes establishment of internal contingency reserves. For executive branch agencies, the apportionment authority is vested in the President (31 U.S.C. § 1513), who in 1933 delegated it to the Bureau of the Budget (the present-day Office of Management and Budget) (Executive Order No. 6,166, Organization of Executive Agencies § 6). Apportionments are intended to prevent agencies from running out of funds before the end of the fiscal year, thereby generating a coercive deficiency. Deficiency apportionments are permissible only in response to laws enacted after budget estimates have already been submitted to Congress and to emergencies involving "the safety of human life, the protection of property, or the immediate welfare of individuals" (31 U.S.C. § 1515). Changes to earlier apportionments are also restricted to emergency conditions (31 U.S.C. $\S 1515(\mathrm{~b})(1)(\mathrm{B}))$.

The fourth and final component of the Antideficiency Act are its enforcement provisions. Officers and employees of the government violating the act are liable to "adverse personnel action," which may extend to suspension without pay or dismissal 
from office (31 U.S.C. $§ 1349$ ), and (in the case of a willful violation) to criminal penalties (a fine of $\$ 5,000$ and/or imprisonment for up to 2 years) (31 U.S.C. § 1350), though actual prosecutions are rare (Peterson 339). Furthermore, all violations are to be reported to the President, Congress, and Comptroller General (31 U.S.C. § 1351). In practice, however, imposition of actual sanctions depends almost exclusively on the executive branch, which alone can decide to impose administrative penalties or bring an indictment before the grand jury (though at least in theory, section 1350 affords a strong basis for an impeachment in the case of a violation of sufficient importance to warrant such a drastic congressional action) (LeBoeuf 490-491; Sidak 1241).

\subsection{Antideficiency Act and the funding gaps}

There are two principal views on the issue of how the Antideficiency Act applies in the event of a funding gap. Under the functionalist one, the Act should not be read to require government shutdowns during lapses in appropriations caused by political deadlocks in Congress, since such lapses have little in common with the concerns that prompted the enactment of the Act and there is nothing to indicate that Congress intended the agencies to terminate their operations in such a case. But on the other hand, the statutory language is clear - no obligations may be incurred in the absence of appropriations - and there is nothing in the Antideficiency Act to suggest an exception from this rule when the absence of appropriations is caused by a funding gap. Hence, the formalist view is that the Antideficiency Act applies in the event of a lapse in appropriations and does not distinguish such circumstance from other instances of absence of appropriations.

Out of these two views of the Antideficiency Act, the former prevailed until the 1970s (General Accounting Office. Funding Gaps Jeopardize Federal Government Operations, B-197841 2; Feld 977-978). It has been best developed in a 1980 GAO opinion, which concluded that while agencies' continued operation during funding gaps technically violated the Antideficiency Act, Congress did not intend them to suspend operations and close down. Under GAO's view, agencies could continue day-to-day operations, but were to refrain from all "non-essential" expenses, such as new hiring, procurement and new programs (General Accounting Office. Interpretation of the Antideficiency Act, 31 U.S.C. § 665, B-197841; accord White, "Views of the Office of Management and Budget on H.R. 5995 and H.R. 5704, Bills Dealing with Federal Pay Continuity"). Accordingly, while a number of funding gaps occurred during the 1970s (Tollestrup, "Federal Funding Gaps..." (3), lists six), none of them resulted in a government shutdown (Tollestrup, "Federal Funding Gaps..." 4 fn. 14).

The situation changed in 1980, when, during a lapse in the Federal Trade Commission's appropriations, Attorney General Benjamin Civiletti issued an opinion interpreting the applicability of the Antideficiency Act during funding gaps (Civiletti, "Applicability..."; see also: Feld 976). The Attorney General rejected the functionalist view, noting the fundamental inconsistency of the position that agencies' continued operations were "unlawful, but authorized." He instead found that "[f]aithful execution of the laws cannot rest on mere speculation that Congress does not want the Executive branch to carry out Congress's unambiguous mandates," and that the plain language of the Antideficiency Act should govern (Civiletti, "Applicability..." 228). Therefore, the Attorney General advised the President that, in the absence of 
additional legislative authorization, agencies could not incur any obligations during a funding gap, even those merely incident to maintaining ongoing operations (229). The opinion expressly noted that requiring agency personnel to work during a gap was by itself a violation of the Act's provisions and responsible agency officials could be subject to criminal prosecutions. Accordingly, under the 1980 opinion, the standard agency response to a funding gap should be to suspend all operations (furloughing all non-exempt personnel) until Congress passes an appropriation act or a continuing resolution. ${ }^{11}$

\subsection{Exceptions to the Antideficiency Act}

Yet neither the Antideficiency Act itself nor the 1980 opinion of Attorney General Civiletti requires a complete shutdown of the government. Successive Congresses that enacted the Antideficiency Act recognized that congressional control of the purse was not the only government interest relevant during the budget implementation, and that excessive rigidity of the appropriations law is undesirable. Therefore, Congress has created a number of exceptions to the provisions of the Act. Furthermore, a January 1981 opinion by Attorney General Civiletti ("Authority...") recognized a number of additional exceptions applicable to funding gaps.

First, an exemption from the provisions of the Anti-Deficiency Act may be expressly created by statute (Principles of Federal Appropriations Law 6-88 - 6-93). Congress may, for instance, authorize an agency to enter into contracts in the absence of appropriations by providing it with a form of budgetary authority known as "contract authority." 12 Dating back to the eighteenth century, contract authority is usually granted for the purpose of enabling the agency to conduct large, multi-year projects without appropriating all funds at the outset (H.R. Rep. No. 93-658 23). Most forms of contract authority are of little relevance to the law of government shutdown. One notable exception is a provision of section 3732 of the Revised Statutes (41 U.S.C. § 11), known as the Feed and Forage Law. This Civil War-era statute (with roots in the 1790s) (Fisher 240-244) authorizes the military and naval establishments to contract for most kinds of supplies without regard to availability of appropriations (Under Secretary of Defense (Comptroller). Department of Defense Financial Management Regulation, DoD 7000.14-R vol. 3, ch. 12). It has been invoked as authority to keep much of the Department of Defense running in the event of a shutdown, but also to fund military operations for which no appropriations

11 While GAO ultimately acquiesced in the construction of the statute established by the Attorney General, it was initially highly critical thereof. A 1981 GAO report to Congress, while refraining from explicit criticism of the Attorney General's legal reasoning, presented a particularly dire picture of consequences of a potential shutdown, and called on the legislative branch to statutorily overrule the 1980 opinion (General Accounting Office, Funding Gaps Jeopardize Federal Government Operations, B-197841). Many of the concerns expressed in that report, however, have been since allayed by expansive interpretation of statutory and implied exceptions to the Antideficiency Act.

12 Examples of contract authority include 40 U.S.C. $\S 3171$ (acquisition of land for public buildings), 42 U.S.C. $\$ 2210$ (indemnification of nuclear energy companies), and 49 U.S.C. $\S 31104$ (federal highway aid to states). Contract authority should not be mistaken with authority to enter into contracts, which is usually implied by the terms of the agency's enabling statute (Principles of Federal Appropriations Law 6-88). 
authority existed (e.g. the bombing of Cambodia in the late stages of the Vietnam War and Operation Desert Shield in 1990) (Raven-Hansen, Banks, "From Vietnam to Desert Shield..." 102-103).

Congress may also authorize agencies to accept voluntary services by statute. Again, most examples, such as the government-wide authority to employ unpaid student interns (5 U.S.C. § 3111) or to procure expert and consultant services (5 U.S.C. § 3109), do not concern funding gaps. However, one exception to the voluntary services prohibition, found in the Antideficiency Act itself, is of critical importance to the law of government shutdown. Section 1342 permits agencies to accept voluntary services in the event of "emergencies involving the safety of human life or the protection of property." 13 The Attorney General has also recognized an analogous exemption to section 1341 (permitting agencies to incur deficiency obligations when necessary to protect lives or property) (Civiletti, "Authority..." 16; see also: Feld 987).

Both the Attorney General (Civiletti, "Authority..." 8) and the GAO (see, e.g.: General Accounting Office, Query Concerning DOD Response to Funding Crisis, B-208985) have read the term "emergencies involving the safety of human life or the protection of property" to exclude ordinary operations of government agencies in the absence of some specific threat to public safety or government property. This reading has been expressly enacted into law in a 1990 amendment to section 1342, providing that the said term "does not include ongoing, regular functions of government the suspension of which would not imminently threaten the safety of human life or the protection of property" (Pub. L. No. 101-508, § 13213(b), 104 Stat. 1388, 1388-621; see also: H.R. Conf. Rep. No. 101-964 1170).

A 1981 memorandum by the Office of Management and Budget (Office of Management and Budget. Memorandum for Heads of Executive Departments and Agencies. Agency Operations in the Absence of Appropriations) identifies eleven broad categories of activities that are likely to qualify for emergency exception to the Antideficiency Act (the list is non-exhaustive): provision of medical care, regulatory activities protecting public health and safety (such as food and drugs or hazardous materials regulation), air traffic control and other transportation safety functions, border protection, federal property maintenance and security, prison maintenance, law enforcement, disaster assistance, "preservation of essential elements" of the financial system (including essential banking and security exchange supervision services, public debt management and tax collection), power distribution and protection of research property.

The 1981 Civiletti opinion also identified a number of extra-textual exceptions to the provisions of the Antideficiency Act. First, obligations exempt from the statutory restrictions on deficiency obligations may arise without agency action. This category includes entitlements, obligations arising from ratified international agreements and arbitral awards, and judgments against the United States (see, e.g.: Settlement and Certification of Judgment Claims, 1 Comp. Gen. 540 (GAO 1922); B-211229, 63 Comp. Gen. 308 (GAO 1984); B-219161, 65 Comp. Gen. 4 (GAO 1983)). It must be noted,

13 Several decisions have read the reference to "property" in the emergency services exception to refer only to property either belonging to the government or remaining in its custody or under its care (Voluntary Services, 9 Comp. Dec. 182, 185 (Comp. Treas. 1902)). 
however, that to qualify for this exemption, an obligation must be absolute (i.e. not contingent on any discretionary action of an agency or officer) (Principles of Federal Appropriations Law 6-87 - 6-88). Furthermore, the exemption does not apply when the obligation could have been satisfied without exceeding the amount of appropriation had the agency reduced its non-mandatory spending (B-133316, 58 Comp. Gen. 46 (GAO 1978)).

The second category of obligations exempt from the Antideficiency Act are those arising "by necessary implication" from other mandatory duties of the agency (Civiletti, "Authority..." 298 fn. 7; Dellinger, "Government..." 80). A classic example is the Social Security Administration - an agency operating a mandatory entitlements program funded from a permanent appropriation, which still depends on annual appropriations for its personnel and operating expenses. As the scope of the program is defined by statute and agency cannot scale it down or suspend it, it may, without violating the Antideficiency Act, continue operations (at least to the extent necessary to keep the program functioning) even if no sufficient appropriation had been made (Feld 982).

The 1981 opinion also identified a third, more controversial class of obligations: those "incident to presidential initiatives undertaken within his constitutional powers" (Civiletti, "Authority..." 299-301). While it is clear that Congress cannot diminish the President's constitutional prerogatives (such as the power to grant pardons, send and receive ambassadors, or make recommendations to Congress) (see, e.g.: Ex parte Garland, 71 U.S. (4 Wall.) 333, 380 (1866); Schick v. Reed, 419 U.S. 256, 266 (1974); Public Citizen v. Department of Justice, 491 U.S. 440, 485 (1989) (Kennedy, J., concurring)), it remains a point of contention whether it is constitutionally required to provide funds for their exercise, and, assuming it is, what options the President has in the event of a breach of that duty (cf. Stith, "Congress' Power..."; Sidak; Peterson 336). The 1981 opinion takes a middle ground - the President can obligate funds for such activities, but may not make actual outlays ("draw money from the Treasury") without an appropriation. This reasoning seems to have been accepted by the GAO, which applied it by analogy to the supporting agencies of the legislative branch itself (General Accounting Office. Comments on Effect of Temporary Funding Hiatus on Legislative Branch Agencies, B-241911). ${ }^{14}$

\section{Overview of modern government shutdowns}

The sweeping changes in the official interpretation of the Antideficiency Act brought about by the 1980 and 1981 opinions apparently had a strong deterrent effect on political and institutional actors involved: while the federal budget became an even more central issue in the political conflict, and a number of lapses in appropriations occurred in the 1980s, they were of very short duration (one to three days, with the

14 Similar reasoning has also been applied by the Court of Appeals for the Ninth Circuit, which held that constitutionally guaranteed jury trials in civil cases may not, in the event of a lapse in appropriations for juror fees, be postponed until funding is restored, notwithstanding the fact that such postponement was necessary to avoid incurring obligations in excess of appropriations. Armster v. United States District Court, 792 F.2d 1423, 1430 (9 $9^{\text {th }}$ Cir. 1986). 
longest ones occurring during three-day weekends) and therefore did not significantly impact agency operations (Tollestrup, "Federal Funding Gaps..." 3-4; Seam, Shron 6-10).

\subsection{The Clinton Era: 1995-1996 shutdowns}

The first significant government shutdown under the modern legal framework occurred in November 1995. It grew out of a conflict between congressional Republicans (who, in 1994, regained control of both houses of Congress for the first time in 40 years) and the White House on the issue of the 1995 budget: Republicans sought to balance the budget as soon as possible, primarily by cutting spending, while the President wanted to protect his preferred programs and agencies: environmental protection and Department of Education ("Government Shuts Down Twice Due to Lack of Funding" 11-3; Meyers 29-30; Schick 228). While three of the thirteen regular appropriation bills were enacted on time (Tollestrup, "Federal Funding Gaps..." 4-5), most of the government was initially funded by a continuing resolution (Pub. L. No. 104-31, 109 Stat. 278) which expired on November 13. A further continuing resolution (H.J. Res. 115) was vetoed by President Clinton on the ground that it contained provisions raising Medicare premiums (Message to the House of Representatives Returning Without Approval Continuing Resolution Legislation; see also "Budget Showdown: Day by Day").

The resulting funding gap lasted five days - being the longest to date since 1980 and caused a shutdown impacting ca. 800,000 employees (Tollestrup, "Federal Funding Gaps..." 5). Ultimately, the Republicans backed down with the premium increases and promised to forego cuts to Medicare, Medicaid, education and environmental protection in exchange for the President's agreement to balance the budget within seven years on the basis of the Congressional Budget Office's economic projections (Williams, Jubb 477; "Government Shuts Down Twice Due to Lack of Funding" 11$-4-11-5)$. But no budget deal was reached before the continuing resolution expired on December 15 (though four more appropriation bills - Transportation, Treasury and General Government, Legislative Branch, and National Defense - were enacted by that time) ("Government Shuts Down Twice Due to Lack of Funding" Appx. 1, 11-6). The ensuing shutdown - by far the longest to date - affected the Departments of State, Justice, Interior, Commerce, Labor, Health and Human Services, Education, Housing, and Veterans Affairs, as well as most independent agencies, foreign operations, and the District of Columbia (Tollestrup, "Federal Funding Gaps..." 5-6, 10).

This time, the funding gap lasted for three weeks, with the House refusing to agree to another continuing resolution without a comprehensive budget deal ("Government Shuts Down Twice Due to Lack of Funding" 11-5 - 11-6). Only when the Senate Republican leadership openly broke with Speaker Newt Gingrich on the issue of reopening the government, the House receded and passed a continuing resolution, which was signed into law on January 6 (Pub. L. No. 104-94, 110 Stat. 25; see also: Seam, Shron 14; Williams, Jubb 479-480), finally ending the shutdown.

\subsection{The Obama Era: 2013 government shutdown}

The 1995 government shutdowns were widely recognized as a public relations defeat for the Republican Party (see: Tyson, "The Last Government...”), with several 
commentators pointing to them as one of the reasons for Republicans losing political momentum in 1996 (Meyers 31). It is not the purpose of this article to determine the correctness of those perceptions, but their very existence has likely affected the behavior of political actors, deterring them from resorting to government shutdowns in future budgetary conflicts for nearly 20 years. Substantial risk of a funding gap reoccurred only in 2010, in circumstances very similar to those of 1995: divided government, with the Republican House challenging the budgetary policies of a Democratic President from a deficit-reduction position. Yet during the first few years of the new political arrangement the parties managed to avoid a shutdown through a series of last-minute compromises (see, e.g.: "Default Avoided at Eleventh Hour" 3-7; Berman, Kasperowicz).

The immediate cause of the next government shutdown was actually a dispute about a rider denying funds for President Obama's signature domestic policy achievement, 2010 health insurance reform legislation, scheduled to come into effect in October 2013. The rider, inserted into the House continuing resolution (H.J. Res. 59) and supported by a group of conservative Republicans led by Congressman Mark Meadows (R-NC) and Senators Ted Cruz (R-TX) and Mike Lee (R-UT), was categorically rejected by the Democratic-controlled Senate (Carney; Bolton, "Senate Rejects House..."; Tollestrup, "Congressional Action on FY2014 Appropriations Measures" 13-14). The shutdown started after the 2013 fiscal year's funding expired on September 30 (Berman), and continued for more than two weeks ("Fiscal Crisis Watch, Week 1: Timeline"; "Fiscal Crisis Watch, Week 2: Timeline"). Budgetary negotiations were soon linked with a related issue of the federal debt ceiling increase, and a comprehensive deal was reached in the Senate on October 16 (Bolton, "Senate Leaders..."; see also: "Highlights of the Continuing Resolution and Debt Limit Deal" and S. Amdt. 2004 to H.R. 2775). The proposed continuing resolution, quickly approved by the House and the President, came into effect on October 17 (Pub. L. No. 113-46, 127 Stat. 558).

\section{Application of a legal framework during recent government shutdowns}

\subsection{Official legal guidance on relevant provisions}

Throughout both the 1995 and the 2013 shutdowns, the executive branch generally adhered to the 1981 Attorney General opinions. In August 1995, Assistant Attorney General Walter Dellinger, head of the OLC, expressly confirmed the applicability of the Civiletti opinions to any potential lapse in appropriations (Dellinger, "Government Operations..."). ${ }^{15}$ Before and during the shutdown itself the OLC issued a number of opinions addressing the operations of the White House Office

15 The 1995 memorandum made one change in the earlier rules - in order to reflect the 1990 amendments to 31 U.S.C. $§ 1342$ (discussed above), OLC determined that to qualify for the emergency services exception to the Antideficiency Act, agency functions not only have to involve protection of life or property, but must be of such importance that in their absence such protection would be compromised "in some significant degree" (Dellinger, "Government Operations..." 78; Brass 5 fn. 24). 
(Dellinger, "Authority to Employ...") and Justice Department (Dellinger, "Effect of Appropriations ...") during funding gaps, and participation by officials of affected agencies in congressional hearings (Dellinger, "Participation in Congressional Hearings...").

The main task of operationalizing the rules set forth in the Antideficiency Act, however, was assigned to the Office of Management and Budget. Accordingly, the question of which activities can continue during a shutdown cannot be answered without resorting to administrative regulations. OMB's current guidance with respect to appropriations lapses is outlined in section 124 of annually-issued Circular A-11 (Preparation, Submission, and Execution of the Budget) ${ }^{16}$, with more detailed instructions set forth in OMB Memorandum M-13-22 (Planning for Agency Operations During a Potential Lapse in Appropriations). These documents direct agency general counsels to identify excepted activities (i.e. those that are funded by permanent appropriations or fall within one of the four OLC-identified exceptions to the Antideficiency Act), in consultation with the OMB (and, when necessary, the OLC). Agencies are also required to prepare and file with the OMB contingency plans, outlining the number of employees to be retained in connection with each excepted activity and procedures for orderly shutting down other agency functions (Circular A-11 § 124:2). ${ }^{17}$

\subsection{Termination of non-excepted agency functions}

For most agencies, non-excepted functions are to be terminated entirely immediately after the lapse of appropriations. While the continuation of some functions (such as procurement and grant awards) would, in and of itself, violate the Antideficiency Act, most are terminated because of personnel furloughs. As requiring employees to report to work would create an obligation on the part of the government to pay them for services rendered (in violation of section 1341), and permitting them to work without pay would be inconsistent with section 1342, virtually all agency employees are instead furloughed without pay (Brass 8-9).

Some government officials, however, are exempt from furloughs: if the obligation to pay compensation arises independently of an officer's or employee's actual performance of official duties, he may continue to work without violating the Antideficiency Act (Dellinger, "Participation in Congressional Hearings..." 301-302; Thompson; Office of Personnel Management. Guidance for Shutdown Furloughs § B.6 2-3). Notable examples include the President, members of Congress, and judges (with respect to whom obligation to pay compensation arises from the Constitution itself); presidential appointees paid under Executive Schedule rates, whose compensation is statutorily attached to their offices (United States v. Grant,

16 Earlier OMB regulations on the matter (which were in force during the 1995 shutdown) were Shutdown of Agency Operations Upon Failure by the Congress to Enact Appropriations, OMB Bulletin No. 80-14 and Agency Plans for Operations During Funding Hiatus, OMB Memorandum M-95-18.

17 FY 2014 shutdown contingency plans for most federal agencies are available online at the OMB website (at http://www.whitehouse.gov/omb/contingency-plans). However, as noted by Brass (19), contingency plans are usually published only a few days before the shutdown, thereby impairing public (and congressional) scrutiny. 
237 F.2d 511 ( $7^{\text {th }}$ Cir. 1956); Thompson 3-4 $)^{18}$; military personnel (Department of Defense. Contingency Plan Guidance for Continuation of Essential Operations... 1; Schmults 27); and D.C. public school teachers (5 U.S.C. \& 6301(2)(ii)). Neither furloughed nor excepted employees are paid during a funding gap, and the former are not entitled to any pay for that period, though it has been uniform congressional practice to direct them to be paid after a funding gap ends (Brass $9 \mathrm{fn}$. 37; see also: Pub. L. No. 104-56, § 124, 109 Stat. 548, 553; Pub. L. No. 113-46, § 115, 127 Stat. 558).

\subsection{Personnel furloughs by agency}

While official aggregate numbers of furloughed and excepted employees for the 2013 shutdown are difficult to obtain, agency contingency plans posted at the OMB website contain a wealth of information about the scale and type of excepted activities. According to these data, out of ca. 2.11 million civilian government employees in agencies for whom data are available ${ }^{19}, 56 \%$ were excepted under diverse authorities. The least-impacted departments were Veterans' Affairs (93\% of personnel excepted), Homeland Security (86\%), Justice (84\%), and Transportation $(67 \%$, most in the Federal Aviation Administration). On the other hand, the federal government's two smallest departments (Housing and Urban Development and Education) shut down nearly completely, each retaining only a few hundred employees (less than $10 \%$ ). Treasury was also significantly affected (only $11 \%$ of employees excepted). Independent agencies were mostly shut down, though the OMB, Office of Personnel Management, Social Security Administration, and General Services Administration each retained a significant number of employees.

Some agencies managed to avoid shutting down non-excepted activities by using additional financial resources that remain available for obligation. Federal courts have been able to avoid major cuts to non-excepted functions by funding their operations from fees and other offsetting collections (Brass 11-12). The Patent and Trademark Office did likewise (Department of Commerce. Plan for Orderly Shutdown Due to Lapse of Congressional Appropriations 83; § 2.2.15). Similarly, the State Department used its extant biannual and no-year appropriations to fund both excepted and non-excepted functions (though at a reduced level) (Department of State. Guidance on Operations During a Lapse in Appropriations 2-4). Such measures, however, were only temporary, and the agencies involved warned that if the shutdown were to last beyond two-three weeks, the stopgap funding would run out.

18 Lower-level offices, though, are not exempted from furloughs, as they are subject to the provisions of the Annual and Sick Leave Act (Pub. L. No. 82-233, Title II, 65 Stat. 679, 5 U.S.C. §§ 6301 et seq.), and 5 U.S.C. $\$ 5508$ expressly states that such officials "are not entitled to the pay of their offices solely because of their status as officers." The President may, however, designate officers of the executive branch (other than postmasters, U.S. attorneys, and U.S. marshals) as excepted from the application of Annual and Sick Leave Act (5 U.S.C. $\S 6301(2)(x i))$, and thereby also exempt them from furlough requirement.

19 One significant group for which no data is available are agencies funded under the National Intelligence Program (Office of the DNI, CIA, NSA, etc.). Another one is comprised of independent entities that are primarily self-financed and therefore not subject to the Antideficiency Act - e.g. Federal Reserve System and FDIC. 
Another department that largely avoided the shutdown was the Department of Defense. Initial DoD guidance, while construing the scope of excepted activities quite broadly (to include planned and contingency military operations, administrative, intelligence, logistical, and medical support, personnel support deemed "essential for readiness" (like childcare), and military benefits payments) (Department of Defense. Contingency Plan Guidance for Continuation of Essential Operations... 4-9; Towell, Belasco 9-12), still resulted in furloughs of about 350,000 employees - approximately half of the Pentagon's civilian workforce (Towell, Belasco 6). However, on September 30, Congress enacted the Pay Our Military Act (Pub. L. No. 113-39, 127 Stat. 532), providing continuing appropriations for pay of uniformed personnel on active duty and of civilian employees supporting them (Towell, Belasco 6-8). On October 5, the Secretary of Defense determined that the statute permitted him to recall most furloughed employees, with only ca. 50,000 remaining subject to the shutdown (Department of Defense. Guidance for Implementation of Pay Our Military Act).

\begin{tabular}{|l|c|c|c|}
\hline \multicolumn{1}{|c|}{ Department } & Total employees & $\begin{array}{c}\text { Excepted and } \\
\text { exempt } \\
\text { employees }\end{array}$ & $\begin{array}{c}\text { Percent } \\
\text { excepted or } \\
\text { exempt }\end{array}$ \\
\hline Veterans' Affairs & 332,025 & 316,742 & $95 \%$ \\
\hline Homeland Security & 231,117 & 199,822 & $86 \%$ \\
\hline Justice & 114,486 & 96,130 & $84 \%$ \\
\hline Transportation & 55,468 & 36,987 & $67 \%$ \\
\hline Health and Human Services & 78,198 & 36,565 & $47 \%$ \\
\hline Energy & 13,814 & 4,043 & $29 \%$ \\
\hline Agriculture & 105,000 & 30,200 & $29 \%$ \\
\hline Interior & 72,562 & 13,789 & $19 \%$ \\
\hline Labor & 16,304 & 2,954 & $18 \%$ \\
\hline Commerce & 46,420 & 6,251 & $13 \%$ \\
\hline Treasury & 99,826 & 10,997 & $11 \%$ \\
\hline Education & 4,225 & 242 & $6 \%$ \\
\hline Housing and Urban & 8,709 & 300 & $3 \%$ \\
\hline Development & 159,284 & 36,414 & $23 \%$ \\
\hline Independent agencies & Per & $5 \times 2 \%$ & \\
\hline
\end{tabular}

Table 1. Executive Departments by Percentage of Employees Excepted (based on shutdown contingency plans available at http:/ / www.whitehouse.gov/omb/contingency-plans $)^{20}$

20 State and Defense Departments contingency plans include no data on the number of excepted employees. Those departments' responses to government shutdown are discussed above. 
Yet another special case was the local government of the District of Columbia. Mayor Grey excepted all officers in the District's executive branch, designating them as "essential" under applicable OMB guidance (District of Columbia Contingency Plan in the Event of a Lapse in Appropriations). A similar measure was passed by the D.C. Council with respect to the District's legislative branch (D.C. Act No. 20-182 D.C. Act No. 20-182, § 2(a)). Only the D.C. court system implemented a partial shutdown (District of Columbia Courts. District of Columbia Courts' Shutdown Plan). However, it is highly implausible that, under a fair reading of the Antideficiency Act, all District government employees would qualify under some exception. ${ }^{21}$ Instead, the D.C. government's action was likely motivated by political considerations related to its ongoing fight for greater budgetary autonomy (see: Sommer). However, the District managed to avoid overt violation of the Antideficiency Act, as on October 4 the D.C. Council voted to fund its continued operations from emergency and contingency cash reserve funds (D.C. Act No. 20-182, §4).

\subsection{Excepted activities}

When looking at the excepted activities outside the Department of Defense (for which no breakdown of excepted employees by category is available) and the D.C. government, it must be noted that most of them - 428,000 out of 832,000 - were not subject to the Antideficiency Act at all, being either funded from multi-year and no-year appropriations, or exempt from furloughs by virtue of other laws. The former group included 285,000 employees of Veterans' Administration and 12,000 of U.S. Citizenship and Immigration Services, as well as 15,000 employees in the Department of Health and Human Services (DHHS) paid from carryover funds. The latter consisted primarily of 43,000 uniformed members of the Coast Guard, 9,000 teachers in the District of Columbia public school system, and the 4,000-member-strong Commissioned Corps of the Public Health Service.

Of more interest for the purposes of this article are functions and employees deemed to qualify for one of the Antideficiency Act exceptions (404,000 in the aggregate). Law enforcement functions (including FBI, ATF, DEA, Bureau of Prisons, U.S. Marshals Service, Secret Service, Immigration and Customs Enforcement, Transportation Security Administration, U.S. Park Police, and Internal Revenue Service) were the largest group, accounting for over 235,000 employees. A further 15,000 employees were excepted as engaged in provision of medical care (mostly in DHHS and DVA, but also in the District of Columbia public hospital system). Finally, 95,000 employees were found to perform other duties necessary for protection of life and property. That number included the Federal Aviation Administration $(25,000)$, inspection services in the Department of Agriculture $(11,800)$, Federal Emergency Management Agency $(11,500)$, U.S. Forest Service $(9,800)$ and National Weather Service $(4,600)$. The Department of Justice classified as necessary for the protection of life and property about 7,000 attorneys in its investigating and litigating divisions and in U.S. Attorney offices around the country. The Department of Interior excepted about 3,300 employees (mostly in the National Park Service, Fish

21 During the 1995 shutdowns most of the D.C. government agencies shut down, and a 2011 shutdown plan estimated the number of excepted and exempt employees at only 21,000 out of 35,000 (District of Columbia. DC Government Shutdown Plan). 
and Wildlife Service, and Bureau of Reclamation). DHHS excepted 2,000 employees to maintain and protect ongoing research experiments and research infrastructure. 4,700 employees were excepted in such independent agencies as the General Services Administration (responsible for maintenance of most federal government buildings), EPA, Nuclear Regulatory Commission, NASA, Securities and Exchanges Commission, Federal Trade Commission (to adjudicate merger approval requests), and USAID (to support operations in foreign countries).

About 44,000 federal employees were excepted because of their participation in activities "necessarily implied" by law. The Social Security Administration and Veterans' Benefits Administration, which process pension payments (funded from permanent appropriations), account for nearly two-thirds of that number. Large numbers of support personnel were also excepted by the Department of Transportation (to supervise ongoing multi-year contracts), Department of Justice, Office of Personnel Management, and Office of Management and Budget (to administer the government-wide shutdown).

Only 180 employees have been identified by agencies as necessary to support the President's constitutional powers. Most of them - 104 - were in the Executive Office of the President, and an additional 70 in the Treasury Department. Many departments (including the Department of Justice and Department of Defense) made no independent determinations of this point, instead including personnel necessary to support the President's constitutional powers among other support personnel.

To summarize, by far the most important exception to the Antideficiency Act has been the emergency services exception, which has been construed (beyond the District of Columbia) quite broadly, though still reasonably: it covered mostly national security and law enforcement activities, public health and safety functions, emergency response, and protection of federal property, but also activities necessary to protect more intangible rights (such as tax collection, securities markets supervision, and civil enforcement of some regulatory statutes). However, shutdown still had a significant effect on a number of government activities, primarily procurement, grant programs, research and development, planning, training and education, and services provided to the public (see: Brass 14-16).

\subsection{Public controversies}

Suspension of services provided to the public was the most controversial issue during the shutdown. A number of Republican congressmen, as well as conservative commentators, claimed that activities which arguably could have continued without violating the Antideficiency Act were terminated by the administration in order to maximize the impact of the shutdown on the public, and therefore pressure Congress to back down. ${ }^{22}$ At issue were primarily closures of national monuments that are normally available to the public 24 hours a day without agency staffing (most notably the World War II Memorial) (Prang; Fears), as well as forced closings of privately-operated facilities in national parks (Dinan). Critics argued that none of these actions were necessary to avoid incurring new obligations, while the National

22 This strategy, known as "closing the Washington Monument," has been a popular (and frequently quite effective) agency response to budget cuts at least since the 1960s (Bernstein; Kennedy). 
Park Service responded that its excepted personnel were insufficient to ensure the safety of visitors (Testimony of Jonathan B. Jarvis, Director, National Park Service). The shutdown of many government websites has also been criticized as unnecessary (see: Restuccia).

It is difficult to determine whether these agency actions were motivated primarily by an overabundance of caution or by an actual intent to increase public pressure on Congress, though the latter explanation is not implausible: in the first week of the shutdown, the Republican-controlled House passed a number of piecemeal continuing resolutions designed to reopen more popular parts of the government (e.g. National Park Service, National Institute of Health, Veteran Benefits Administration, Food and Nutrition Service) ("Status of Appropriations Legislation for Fiscal Year 2014"; Tollestrup, "Congressional Action..." 15), but none of them were taken up by the Senate. The Democratic leadership argued that these "mini-CRs" would minimize public pressure for a quick resolution to the shutdown (Cox), and President Obama threatened to veto them for that reason (Office of Management and Budget. Statement of Administration Policy on Limited Appropriations Resolutions).

\section{Reform proposals}

As has been the case before, the 2013 shutdown has spawned a number of reform proposals designed to avoid future government shutdowns. One way to achieve this goal would be an "automatic continuing resolution" (ACR) - a legislative device that would automatically provide some basic funding for government programs in the event of a lapse of regular appropriations (Tollestrup, Automatic Continuing Resolutions..." 4-6). However, automatic continuing resolutions have numerous drawbacks (6-13). First, they could significantly weaken the power of the purse by taking away from Congress its ability to completely cut funding to some or all government activities through mere legislative inaction. Second, most ACR proposals would not be politically neutral, but instead would strongly favor the budgetary status quo by adopting as a point of reference previous-year funding levels. ${ }^{23}$ Finally, an ACR would raise constitutional doubts as to whether Congress can enact what in practice amounts to a permanent appropriation for most government operations.

Another proposed solution would be to approve in advance retroactive pay to furloughed employees (H.R. 3223). Such a measure would effectively except all furloughed employees from the Antideficiency Act (as their return to work would no longer create any additional obligation on the part of the government). While this would not fully reopen the government, it would restore pre-1980 government shutdown rules: agencies could operate with full personnel levels, though they would have to abstain from incurring new obligations. H.R. 3223 was passed by the House

23 Unlike continuing resolutions (Tollestrup, "Continuing Resolutions..." 7), ACR would not be able to set provisional spending levels with reference to the figures set forth in the pending House and Senate appropriation bills, as such reference to the provisions of future bills passed only by one house of Congress (or just reported by a committee thereof) would violate the presentment clause under Immigration and Naturalization Service v. Chadha, 462 U.S. 919 (1983). 
on October 5 (House Roll Call No. 525), but has not been taken up in the Senate. ${ }^{24}$ Unfortunately, many of the objections against an ACR would apply to H.R. 3223 as well.

In fact, it appears that any legislative scheme designed to fully avoid government shutdowns would suffer from the same disadvantages. Congress simply can't have it both ways: to preserve full control over the purse while avoiding any risk of government shutdowns. Each measure that would permit the executive branch to function without affirmative legislative action by Congress would significantly alter the inter-branch balance of power. Instead, Congress should probably focus on improving the legal framework for government shutdowns: defining excepted activities with greater precision and potentially reconsidering which functions should and which should not be excepted.

\section{Conclusion}

Effects of government shutdowns are rightly seen as highly negative. They include disruption of needful government services, significant waste of financial resources (due to termination and restarting of agency activities), and furloughs and delays in disbursements, which negatively affect a large number of government employees and contractors. Labonte cites several estimates of the economic impact of the 2013 shutdown, ranging from a 0.1 to 0.6 percentage point drop in the quarterly GDP growth (6-7). But shutdowns are a necessary cost of the American system of checks and balances, which places numerous obstacles on the attainment of any long-term policy objective without a broad compromise, thus making political deadlocks in contested areas of public policy (such as budgeting) somewhat inevitable (Williams, Jubb 481, 483). The protection against government shutdown must be sought in political processes: the Constitution was not written to safeguard against a total breakdown of political cooperation among the branches. As Justice Jackson put it in Youngstown Sheet \& Tube Co. v. Sawyer (343 U.S. 579 (1952)), "it contemplates that practice will integrate the dispersed powers into a workable government. It enjoins upon its branches separateness but interdependence, autonomy but reciprocity." Without a political compromise among the political branches, no institutional solution can force them to comply with this injunction.

If shutdowns cannot be fully avoided, the question of how they should be regulated becomes of major importance. The present statutory scheme, based on the Antideficiency Act, as interpreted by Attorney General Civiletti and successive heads of the OLC and OMB, generally operates quite well in practice. It protects the purpose of the Constitution's Appropriations Clause by preventing agencies from operating without congressional authority, but it is also flexible enough to permit most essential government activities - national security operations, law enforcement, administration of health and safety regulations, protection of human life and property - to proceed.

${ }^{24}$ Retroactive pay for furloughed employees has been ultimately approved by Pub. L. No. 113-46, 127 Stat. 558 (continuing resolution ending the shutdown) (§ 115). Because this authorization was passed after the shutdown ended, it involved none of the consequences of an advance approval of retroactive pay discussed herein. 
This is not to say, however, that the relevant legal framework is not capable of improvement. It can be argued that Congress should play a greater role in designating which government activities should be excepted and which should not, for instance by providing more detailed statutory guidance or even by making program-by-program designations. Moreover, a high level of generality of the existing statutory framework results in non-uniform application among agencies. Finally, expansive construction of the Antideficiency Act on which existing rules are based can potentially serve as a precedent for claiming similarly broad exceptions in other contexts, thereby eroding the Act's valuable function as a check on the executive branch. However, while there have been some political controversies about shutdown plans and their implementation, it is clear that most agencies' conduct during the funding gap represents a good faith attempt to faithfully implement the relevant legal rules in a complex situation involving difficult choices among competing policy values.

\section{References}

As Difficult As Possible: The National Park Service's Implementation of the Government Shutdown. Joint Oversight Hearing Before the House Committee on Natural Resources and the House Committee on Oversight and Government Reform. Web. 9 April 2014. http:/ / oversight.house.gov/hearing/difficult-possible-national-park-services-implemen tation-government-shutdown/.

Baldwin, Abraham. "Report of the Select Committee to Examine the State of the Treasury Department." 1794. Control of Federal Expenditures: A Documentary History, 1775-1894. Ed. Fred Wilbur Powell. Washington, D.C.: Brookings Institution, 1939.

Berman, Russell. "Government Shuts Down as Lawmakers Miss Funding Deadline." The Hill 1 October 2013. Web. 4 April 2014. http://thehill.com/homenews/house/ 325695-clock-strikes-on-shutdown-as-lawmakers-miss-funding-deadline.

Berman, Russell, and Pete Kasperowicz. "House Approves 'Fiscal Cliff' Deal; Bill Headed to Obama's Desk." The Hill 2 January 2013. Web. 4 April 2014. http://thehill.com/ homenews/senate/275101-senate-fiscal-cliff-deal-in-trouble-in-house.

Bernstein, Jonathan. "The 'Washington Monument' Sequester Strategy." Washington Post Post-Partisan 19 February 2013. Web. 14 April 2014. http://www.washingtonpost.com/ blogs/post-partisan/wp/2013/02/19/the-washington-monument-sequester-strategy/.

Bolton, Alexander. "Senate Leaders Strike Deal to End Shutdown, Raise Debt Ceiling." The Hill 16 October 2013. Web. 5 April 2014. http://thehill.com/homenews/ senate/328811-senate-leaders-strike-deal-expect-quick-house-action.

Bolton, Alexander. "Senate Rejects House Funding Bill with Government Shutdown in Clear Sight." The Hill 30 September 2013. Web. 4 April 2014. http://thehill.com/homenews/ senate/325519-senate-rejects-house-bill-with-shutdown-in-clear-sight.

Brass, Clinton T. "Shutdown of the Federal Government: Causes, Processes, and Effects." Congressional Research Service Report RL34680. 2013. Web. 15 March 2014. https:// www.fas.org/sgp/crs/misc/RL34680.pdf.

"Budget Concepts." Budget of the United States Government, Analytical Perspectives, Fiscal Year 2014. Ed. Office of Management and Budget. Washington, D.C.: Government Printing Office, 2013.

“Budget Showdown: Day by Day." CQ Weekly 18 November 1995. Web. 19 March 2014. http:/ /library.cqpress.com/cqweekly//toc.php?mode=weekly-topic\&level=3\&values= Budget 1995\#. 
Carney, Eliza N. “Once More Unto the Brink.” CQ Weekly 30 September 2013. Web. 2 April 2014. http://www.cq.com/doc/weeklyreport-4352225.

Carvin, Michael A. "Re: Independent Counsel's Authority to Accept Voluntary Services Appointment of Laurence W. Tribe." Office of Legal Counsel Memorandum for Francis A. Keating II, Acting Associate Attorney General. 19 May 1988. Westlaw. Web.

Casper, Gerhard. "Appropriations of Power." University of Arkansas at Little Rock Law Review 13: 1990 (1) Westlaw. Web.

Civiletti, Benjamin R. "Applicability of Antideficiency Act upon a Lapse in Agency Appropriation." Opinions of the Attorney General 43:224. 1980.

Civiletti, Benjamin R. "Authority for the Continuance of Government Functions During a Temporary Lapse in Appropriations." Opinions of the Attorney General 43:293. 1981.

Civilian Personnel Law Manual. Washington, D.C.: General Accounting Office, 1991.

Clinton, William Jefferson. "Message to the House of Representatives Returning Without Approval Continuing Resolution Legislation." Weekly Compilation of Presidential Documents 31:2025. 13 November 1995.

Cox, Ramsey. "Reid Fefuses to Consider Piecemeal House Funding Measures." The Hill Floor Action. 3 October 2013. Web. 10 April 2014. http://thehill.com/blogs/floor-action/ senate/326363-reid-refuses-to-consider-piecemeal-house-funding-measures.

Currie, David P. The Constitution in Congress: The Federalist Period, 1789-1801. Chicago, IL: University of Chicago Press, 1997.

“Default Avoided at Eleventh Hour." Congressional Quarterly Almanac 67: 2011 (3-7 - 3-9). Web. 7 April 2014. https:/ / library.cqpress.com/cqalmanac/document.php?id=cqal-139077513-2462134.

Dellinger, Walter. "Authority to Employ the Services of White House Office Employees During an Appropriations Lapse." Opinions of the Office of Legal Counsel 19:235. 13 September 1995.

Dellinger, Walter. "Effect of Appropriations for Other Agencies and Branches on the Authority to Continue Department of Justice Functions During the Lapse in the Department's Appropriations." Opinions of the Office of Legal Counsel 19:337. 13 December 1995.

Dellinger, Walter. "Government Operations in the Event of a Lapse in Appropriations." O.L.C. LEXIS 1995:57. Unpublished O.L.C. memorandum for Alice Rivlin, Director, Office of Management and Budget. 19 September 1995. Rptd. in Effects of Potential Government Shutdown. Hearing before the Senate Committee on the Budget. S. Hrg. 104-175. Washington, D.C.: Government Printing Office, 1995.

Dellinger, Walter. "Participation in Congressional Hearings During an Appropriations Lapse." Opinions of the Office of Legal Counsel 19:301. 16 November 1995.

Department of Agriculture. Shutdown Procedures. Web. 27 March 2014. http://www.usda. gov/shutdown_procedures.html.

Department of Commerce. Plan for Orderly Shutdown Due to Lapse of Congressional Appropriations. 1 October 2013. Web. 27 March 2014. http://www.commerce.gov/sites/default/ files/documents/2013/september/2013_doc_lapse_in_appropriations_plan_9_27.pdf.

Department of Defense. Contingency Plan Guidance for Continuation of Essential Operations in the Absence of Available Appropriations. 1 September 2013. Web. 27 March 2014. http:/ /www. defense.gov/home/features/2013/0913_govtshutdown/Contingency-Plan-Guidance-Attachment.pdf.

Department of Defense. Guidance for Implementation of Pay Our Military Act. 5 October 2013. Web. 27 March 2014. http://www.defense.gov/pubs/POMA-implementationguidance.pdf.

Department of Education. Contingency Plan for Lapse in FY 2014 Appropriation. 27 September 2013. Web. 28 March 2014. http://www.whitehouse.gov/sites/default/files/omb/contingencyplans/2013/education-contingency-plan2013.pdf. 
Department of Energy. Implementation Activities in the Case of a Lapse of Appropriations. 2 October 2013. Web. 28 March 2014. http://energy.gov/articles/department-energy-imple mentation-activities-case-lapse-appropriations.

Department of Health and Human Services. Contingency Staffing Plan for Operations in the Absence of Enacted Annual Appropriations. 27 September 2013. Web. 28 March 2014. http:// www.hhs.gov/budget/fy2014/fy2014contingency_staffing_plan-rev2.pdf.

Department of Homeland Security. Procedures Relating to a Federal Funding Hiatus. 27 September 2013. Web. 28 March 2014. http://www.dhs.gov/sites/default/files/publications/ dhs-lapse-contingency-plan-09-27-2013_0.pdf.

Department of Housing and Urban Development. FY2013 Contingency Plan for Possible Lapse in Appropriations. Second Ed. Updated 11 October 2013. Web. 28 March 2014. http:// por tal.hud.gov/hudportal/documents/huddoc?id=HUDContingencyPlan2013.pdf.

Department of the Interior. Contingency Plan for Operations in the Absence of FY 2014 Appropriations. 26 September 2013. Web. 27 March 2014. http:/ / www.doi.gov/shutdown/fy2014/ upload/DOI-Summary-Contingency-Plan.pdf.

Department of Justice. FY2014 Contingency Plan. 11 October 2013. Web. 27 March 2014. http:/ / www.justice.gov/jmd/publications/doj-contingency-plan.pdf.

Department of Labor. Second Update to April 7, 2011, Plan for Continuation of Certain Limited Departmental and Solicitor Activities during a Lapse in Appropriations. 25 September 2013. Web. 28 March 2014. http://www.dol.gov/opa/media/press/opa/shutdown_plan2013.pdf.

Department of State. Guidance on Operations During a Lapse in Appropriations. 27 September 2013. Web. 27 March 2014. http://www.state.gov/m/rls/2013/214880.htm.

Department of the Treasury. Lapse of Appropriations Plan. 1 October 2013. Web. 27 March 2014. http:/ / www.treasury.gov/ connect/blog/Documents/DO\%20Lapse\% 20Contingency\%20Plan\%20FINAL_100113.pdf.

Department of Veterans' Affairs. Agency Operations in the Absence of Appropriations. 27 September 2013. Web. 28March 2014. http://www.va.gov/opa/docs/VA_Contingency_Plan_ Document_20130927.pdf.

Devens, Charles. "Support of the Army." Opinions of the Attorney General 15:209. 1877.

Devins, Neal E. “Appropriations Redux: A Critical Look at the Fiscal Year 1988 Continuing Resolution." Duke Law Journal 1988: 389.

Dinan,Stephen. “National Park Rangers Ordered to Keep Visitors Out of Privately Run Businesses." Washington Times 6 October 2013. Web. 10 April 2014. http:/ / www.washingtontimes. $\mathrm{com} /$ news/2013/oct/6/national-park-rangers-ordered-to-keep-visitors-out/?page=all.

District of Columbia Contingency Plan in the Event of a Lapse in Appropriations. Letter to Sylvia M. Burwell, Director, Office of Management and Budget. By Gray, Vincent C. 25 September 2013. Web. 13 April 2014. http://online.wsj.com/public/resources/documents/ GrayLetter.pdf.

District of Columbia Courts. District of Columbia Courts' Shutdown Plan. 27 September 2013. Web. 13 April 2014. http:// www.dccourts.gov/internet/documents/shutdownplan9-27.pdf.

District of Columbia. DC Government Shutdown Plan. 8 April 2011. Web. 15 April 2014. https:/ / web.archive.org/web/20110413041254/http://government.dc.gov/DC/MAYOR/Publication\%20Files/Shutdown_Powerpoint_040811.pdf.

Effects of Potential Government Shutdown. Joint Hearing Before the Senate Committee on the Budget and the House Committee on the Budget. S. Hrg. 104-175. 104 ${ }^{\text {th }}$ Cong., $1^{\text {st }}$ Sess. 19 September 1995.

Environmental Protection Agency. Contingency Plan for Shutdown. 1 October 2013. Web. 29 March 2014. http:/ / www.epa.gov/lapse/resources/epa-contingency-plan-2013.pdf.

Executive Office of the President. Contingency Shutdown Plan - Operations in the Absence of Appropriations. 26 September 2013. Web. 25 March 2014. http://www.whitehouse.gov/ sites/default/files/docs/eop_contingency_plan.pdf. 
Executive Order No. 6,166. Organization of Executive Agencies. 10 June 1933. Codified as 5 U.S.C. $\S 901$ note (2012 ed.).

Fay, William C., and Michelle D. Rodgers. "Appropriations for Mandatory Expenditures." Harvard Law School. Federal Budget Policy Seminar. Briefing Paper No. 17. 2008. Web. 23 March 2014. http://www.law.harvard.edu/faculty/hjackson/Mandatory Spending_17(rev).pdf.

Fears, Darryl. "Amid Anger Over Closures, Park Service Stays Resolute." Washington Post 16 October 2013. Web. 10 April 2014. http://www.washingtonpost.com/national/ health-science/ seven-reasons-why-the-national-parks-service-closed-the-world-war-iimemorial/2013/10/15/a3df8584-35d5-11e3-be86-6aeaa439845b_story.html.

Federal Pay Continuity Act (H.R. 5595). Hearings Before the Subcommittee on Compensation and Employment Benefits of the House Committee on the Post Office and Civil Service. Serial No. 96-84. 96 $6^{\text {th }}$ Cong., $2^{\text {nd }}$ Sess. 5 and 7 February and 30 April 1980.

Feld, Alan L. "Shutting Down the Government." Boston University Law Review 69: 1989: 971-989.

“Fiscal Crisis Watch, Week 1: Timeline.” CQ Weekly 7 October 2013. Web. 2 April 2014. http:/ / www.cq.com/doc/weeklyreport-4357278.

"Fiscal Crisis Watch, Week 2: Timeline." CQ Weekly 14 October 2013. Web. 2 April 2014. http:/ / www.cq.com/doc/weeklyreport-4361450.

Fisher, Louis. Presidential Spending Power. Princeton, N.J.: Princeton University Press, 1975. Print.

General Accounting Office. Comments on Effect of Temporary Funding Hiatus on Legislative Branch Agencies. B-241911. 23 October 1990.

General Accounting Office. Funding Gaps Jeopardize Federal Government Operations. Report to Congress. B-197841. 3 March 1981. PAD-81-31.

General Accounting Office. Interpretation of the Antideficiency Act, 31 U.S.C. § 665. Report for the Subcommittee on Compensation and Employment Benefits of the House Committee on the Post Office and Civil Service. B-197841. 3 March 1980.

General Accounting Office. Inventory of Accounts With Spending Authority and Permanent Appropriations (1997 Supplement). Report to the Committee on Budget, U.S. Senate. OGC-98-23, B-266063. 19 January 1998.

General Accounting Office. Inventory of Accounts With Spending Authority and Permanent Appropriations. Report to the Committee on Budget, U.S. Senate. GAO/AIMD-96-79, B-260063. 31 May 1996.

General Accounting Office. Query Concerning DOD Response to Funding Crisis. B-208985. 5 October 1982.

General Services Administration. Operations in the Absence of Appropriations. ADM 4220.1H. 27 September 2013. Web. 28 March 2014. http://gsa.gov/portal/directive/d0/content/ 612334.

"Government Shuts Down Twice Due to Lack of Funding." Congressional Quarterly Almanac 51: 1995 (11-3 - 11-6). Web. 5 April 2014. http://library.cqpress.com/cqalmanac/document.php?id=cqa195-1099661.

H.R. Conf. Rep. No. 101-964. Conference Report to Accompany H.R. 5835, Omnibus Budget Reconciliation Act of 1990. 101 ${ }^{\text {st }}$ Cong., $2^{\text {nd }}$ Sess. 1990 U.S.C.C.A.N. 2374. 1990 WL 201626 (Leg. Hist.).

Hamilton, Alexander. "Report on the Estimate of Expenditures for 1792." 1791. The Papers of Alexander Hamilton (Digital Edition). Ed. Syrett, Harold C. Charlottesville, VA: University of Virginia Press, Rotunda, 2011. 9:456.

"Highlights of the Continuing Resolution and Debt Limit Deal." CQ Weekly 21 October 2013. Web. 2 April 2014. http:/ / www.cq.com/doc/weeklyreport-4364083.

House Committee on Rules. H.R. Rep. No. 93-658. Report to Accompany H.R. 7130, Budget 
and Impoundment Control Act. 93 ${ }^{\text {rd }}$ Cong., $1^{\text {st }}$ Sess. 1974 U.S.C.C.A.N. 3462. 1973 WL 12545 (Leg. Hist.).

House Practice: A Guide to the Rules, Precedents and Procedures of the House. Ed. Brown, Wm. Holmes, Charles W. Johnson, John V. Sullivan. Washington, D.C.: Government Printing Office, 2011.

Internal Revenue Service. FY 2014 Shutdown Contingency Plan (During Lapsed Appropriations). Non-Filing Season. 26 September 2013. Web. 28 March 2014. http://www.treasury.gov/ connect/blog/Documents/FY2014\%20Shutdown\%20Plan_Non-Filing-Final-093013\%20 Update.pdf.

Kennedy, Shirley Duglin. “The Washington Monument Syndrome." Information Today 26: 2009 (4): 13.

Krishnakumar, Anita S. "Reconciliation and the Fiscal Constitution: The Anatomy of the 1995-96 Budget Train Wreck." Harvard Journal on Legislation 35: 1989: 589.

Krutz, Glen S. Hitching a Ride: Omnibus Legislating in the U.S. Congress. Columbus, OH: Ohio State University Press, 2001.

Labonte, Marc. “The FY2014 Government Shutdown: Economic Effects." Congressional Research Service Report R43292. 2013. Web. 15 April 2014. https:/ /www.fas.org/sgp/crs/ misc/R43292.pdf.

LeBoeuf, Jacques B. “Limitations on the Use of Appropriations Riders by Congress to Effectuate Substantive Policy Changes." Hastings Constitutional Law Quarterly 19: 1992: 457.

Madison, James. "The Federalist No. 58." 1788. The Federalist Papers. Ed. George W. Carey, James McClellan. Indianapolis, IN: Liberty Fund, 2001. 300.

Małajny, Ryszard M. Amerykański prezydencjalizm. Warszawa: Wydawnictwo Sejmowe, 2012.

Małajny, Ryszard M. Pozycja ustrojowa Kongresu USA. Katowice: Wydawnictwo Uniwersytetu Śląskiego, 1992-1995.

Meyers, Roy T. "Late Appropriations and Government Shutdowns: Frequency, Causes, Consequences, and Remedies." Public Budgeting \& Finance 17: 1997: 25-38. Web. 15 March 2014. http:/ / userpages.umbc.edu/ meyers/govtshutdowns.pdf.

Moore, Kathryn L. "Social Security in an Era of Retrenchment: What Would Happen if the Social Security Trust Funds Were Exhausted?" ABA Journal of Labor E Employment Law 28: 2012: 43.

Office of Management and Budget. Agency Plans for Operations During Funding Hiatus. OMB Memorandum M-95-18. 22 August 1995. Web. 20 March 2014. http://www.whitehouse. gov/sites/default/files/omb/memoranda/m95-18.pdf.

Office of Management and Budget. Memorandum for Heads of Executive Departments and Agencies. Agency Operations in the Absence of Appropriations. 17 November 1981. Web. 20 March 2014. https:// www.opm.gov/policy-data-oversight/ pay-leave/furlough-guidance/attach ment_a-4.pdf.

Office of Management and Budget. Planning for Agency Operations During a Potential Lapse in Appropriations. OMB Memorandum M-13-22. 17 September 2013. Web. 20 March 2014. http:/ / www.whitehouse.gov/sites/default/files/omb/memoranda/2013/m-13-22.pdf.

Office of Management and Budget. Preparation, Submission, and Execution of the Budget. OMB Circular A-11. 26 July 2013. Web. 20 March 2014. http://www.whitehouse.gov/omb/ circulars_a11_current_year_a11_toc.

Office of Management and Budget. Shutdown of Agency Operations Upon Failure by the Congress to Enact Appropriations. OMB Bulletin No. 80-14. 28 August 1980. Web. 20 March 2014. http:/ / www.opm.gov/policy-data-oversight/ pay-leave/furlough-guidance/attach ment_a-5.pdf.

Office of Management and Budget. Statement of Administration Policy on H.J. Res. 70, 71, 72, 73 and H.R. 3230 - Limited Appropriations Resolutions, 2014. 2 October 2013. Web. 13 April 2014. 
http://www.whitehouse.gov/sites/default/files/omb/legislative/sap/113/saphrj7071-72-73_hr3230hr_20131002.pdf.

Office of Personnel Management. Contingency Plan for the Suspension of Operations in the Absence of Appropriations. 3 October 2013. Web. 27 March 2014. http://www.opm.gov/about-us/ open-government/about-open-gov/opm-plan-for-the-suspension-of-operations-in-theabsence-of-appropriations.pdf.

Office of Personnel Management. Guidance for Shutdown Furloughs. 11 October 2013. Web. 20 March 2014. http://www.opm.gov/policy-data-oversight/pay-leave/furlough-gui dance/guidance-for-shutdown-furloughs.pdf.

"Offsetting Collections and Offsetting Receipts." Budget of the United States Government, Analytical Perspectives, Fiscal Year 2014. Ed. Office of Management and Budget. Washington, D.C.: Government Printing Office, 2013.

Oleszek, Walter J. Congressional Procedures and the Policy Process. Washington, D.C.: CQ Press, 2010.

Olson, Theodore B. "Payment of Travel Costs to Witnesses During a Period of Lapsed Appropriations." Opinions of the Office of Legal Counsel 5: 429. 23 December 1981.

Peterson, Todd D. "Protecting the Appropriations Power: Why Congress Should Care About Settlements at the Department of Justice." Brigham Young University Law Review 2009: 327.

Prang, Allison. "World War II Memorial Becomes Shutdown Central." Wall Street Journal - Washington Wire. 2 October 2013. Web. 11 April 2014. http://blogs.wsj.com/ washwire/2013/10/02/world-war-ii-memorial-becomes-shutdown-central/.

Principles of Federal Appropriations Law, $3^{\text {rd }}$ ed. Washington, D.C.: Government Accountability Office, 2004-2012.

Raven-Hansen, Peter, and. William C. Banks. "From Vietnam to Desert Shield: The Commander in Chief's Spending Power." Iowa Law Review 81: 1995: 79.

Raven-Hansen, Peter, and William C. Banks. "Pulling the Purse Strings of the Commander in Chief." Virginia Law Review 80: 1994 (4): 833-944.

Restuccia, Andrew. "Government Shutdown: Why Are Only Some Federal Websites Shut Down?" Politico 10 October 2013. Web. 10 April 2014. http://www.politico. com/story/2013/10/government-shutdown-federal-websites-shut-down-98098.html.

Rubin, Irene S. "Understanding the Role of Conflict in Budgeting." Handbook of Government Budgeting. Ed. Roy T. Meyers. San Francisco, CA: Jossey-Bass, 1999.

Schick, Allen. The Federal Budget: Politics, Policy, Process. Washington, D.C.: Brookings Institution Press, 2007.

Schmults, Edward C. "Meeting the Uniformed Military Services' Payroll During a Period of Lapsed Appropriations." Opinions of the Office of Legal Counsel 6: 27. 25 August 1982.

Seam, Puja, and Brad Shron. "Government Shutdowns." Harvard Law School. Federal Budget Policy Seminar. Briefing Paper No. 10. 2005. Web. 12 March 2014. http://www.law. harvard.edu/faculty/hjackson/GovernmentsShutdowns_10.pdf.

Securities and Exchange Commission. Plan of Operations During an SEC Shutdown. 27 September 2013. Web. 29 March 2014. http://www.sec.gov/about/sec-plan-of-operations-during-lapse-in-appropriations-2013.pdf.

Senate Committee on Government Operations. S. Doc. No. 87-11. Financial Management in the Federal Government. $87^{\text {th }}$ Cong., $1^{\text {st }}$ Sess.

Sidak, J. Gregory. “The President's Power of the Purse.” Duke Law Journal 1989: 1162.

Simms, Larry L. "Continuation of Agency Activities During a Lapse in Both Authorization and Appropriation." Opinions of the Office of Legal Counsel 6: 555. 17 September 1982. Social Security Administration. Status of Service Activities During a Funding Lapse. 25 September 2013. Web. 28 March 2014. http:/ / www.socialsecurity.gov/pressoffice/shutdown2013.pdf.

Sommer, Will. “Open Government.” LooseLips. 2 October 2013. Web. 5 April 2014. http:// www.washingtoncitypaper.com/blogs/looselips/2013/10/02/open-government/. 
“Status of Appropriations Legislation for Fiscal Year 2014." THOMAS. Web. 15 April 2014. http://thomas.loc.gov/home/approp/app14.html.

Stith, Kate. "Congress' Power of the Purse." Yale Law Journal 97: 1988: 1343.

Stith, Kate. "Rewriting the Fiscal Constitution: The Case of Gramm-Rudman-Hollings." California Law Review 76: 1988: 593.

Testimony of Jonathan B. Jarvis, Director, National Park Service. Oct. 16, 2013. As Difficult As Possible: The National Park Service's Implementation of the Government Shutdown, Joint Oversight Hearing Before the House Committee on Natural Resources and the House Committee on Oversight and Government Reform. Web. 9 April 2014. http://naturalresources. house.gov/UploadedFiles/10_16_13_NPS_Testimony.pdf.

Thompson, Karl R. "Authority to Employ White House Office Personnel Exempt From the Annual and Sick Leave Act Under 5 U.S.C. 6301(2)(x) and (xi) During an Appropriations Lapse." Opinions of the Office of Legal Counsel 36 (preliminary print). 8 April 2011. Web. 23 March 2014. http://www.justice.gov/olc/opiniondocs/wh-offrs-exempt-fromeave.pdf.

Tollestrup, Jessica. "Automatic Continuing Resolutions: Background and Overview of Recent Proposals." Congressional Research Service Report R41948. 2013. Web. 7 April 2014. www.fas.org/sgp/crs/misc/R41948.pdf.

Tollestrup, Jessica. "Congressional Action on FY2014 Appropriations Measures." Congressional Research Service Report R43338. 2013. Web. 4 April 2014. www.fas.org/sgp/crs/ misc/R43338.pdf.

Tollestrup, Jessica. "Continuing Resolutions: Overview of Components and Recent Practices." Congressional Research Service Report R42647. 2013. Web. 22 March 2014. www.fas. org/sgp/crs/misc/R42647.pdf.

Tollestrup, Jessica. "Federal Funding Gaps: A Brief Overview." Congressional Research Service Report RS20348. 2013. Web. 11 March 2014. www.fas.org/sgp/crs/misc/ RS20348.pdf.

Tollestrup, Jessica. "Omnibus Appropriations Acts: Overview of Recent Practices." Congressional Research Service Report RL32473. 2010. Web. 19 March 2014. www.hsdl. org/ ?view\&did=719050.

Towell, Pat, and Amy Belasco. “Government Shutdown: Operations of the Department of Defense During a Lapse in Appropriations." Congressional Research Service Report R41745. 2013. Web. 31 March 2014. www.fas.org/sgp/crs/natsec/R41745.pdf.

Tyson, Alec. "The Last Government Shutdown and Now: a Different Environment." Fact Tank - Our Lives in Numbers. Pew Research Center. 2013. Web. 6 April 2014. http:/ /www. pewresearch.org/fact-tank/2013/09/30/the-last-government-shutdown-and-nowa-different-environment/.

Ulman, Leon. "The White House Office - Acceptance of Voluntary Service." Opinions of the Office of Legal Counsel 2: 322. 27 January 1977.

Ulman, Leon. "Employment of Temporary or Intermittent Attorneys and Investigators by Office of the Special Counsel, Merit Systems Protection Board." Opinions of the Office of Legal Counsel 3: 8. 7 February 1979.

Under Secretary of Defense (Comptroller). Department of Defense Financial Management Regulation. DoD 7000.14-R. Volume 7A. Military Pay Policy - Active Duty and Reserve Pay. April 2013. Web. 5 April 2014. http://comptroller.defense.gov/Portals/45/documents/fmr/ current/07a/Volume_07a.pdf.

White, John P. “Views of the Office of Management and Budget on H.R. 5995 and H.R. 5704, Bills Dealing with Federal Pay Continuity." 1980. Federal Pay Continuity Act (H.R. 5595). Hearings Before the Subcommittee on Compensation and Employment Benefits of the House Committee on the Post Office and Civil Service. Washington, D.C.: Government Printing Office, 1980. 
White, Leonard D. The Federalists. A Study in Administrative History. New York, NY: Macmillan Co., 1948.

White, Leonard D. The Jacksonians. A Study in Administrative History, 1829-1861. New York, NY: Macmillan, 1954.

White, Leonard D. The Jeffersonians. A Study in Administrative History, 1801-1829. New York, NY: Macmillan, 1951.

White, Leonard D. The Republican Era, 1869-1901. A Study in Administrative History. New York, NY: Macmillan, 1958.

Wickersham, George W. "Employment of Retired Army Officer as Superintendent of Indian School." Opinions of the Attorney General 30: 51. 1913.

Williams, Robert, and Esther Jubb. "Shutting Down Government: Budget Crises in the American Political System." Parliamentary Affairs 49: 1996 (3): 471-484. Web. 28 March 2014. http://pa.oxfordjournals.org/content/49/3/471.extract.

Wilmerding, Lucius. The Spending Power: A History of the Efforts of Congress to Control Expenditures. Hamden, Conn.: Archon Books, 1971.

Woon, Jonathan, and Sarah E. Anderson. "Political Bargaining and the Timing of Congressional Appropriations." Legislative Studies Quarterly 37: 2012(4): 409-436. DOI: 10.1111/j.1939-9162.2012.00056.x.

\section{Statutes}

An Act further to amend the several acts for the establishment and regulation of the Treasury, War and Navy departments. Mar. 3, 1809. $10^{\text {th }}$ Cong., $2^{\text {nd }}$ Sess., c. 28. 2 Stat. 535 (1809).

An Act in Addition to the Several Acts for the Establishment and Regulation of the Treasury, War, and Navy Departments. May 1, 1820. $16^{\text {th }}$ Cong., $1^{\text {st }}$ Sess., c. 52.3 Stat. 567 (1820).

An Act making Appropriations for the Legislative, Executive, and Judicial Expenses of the Government for the Year ending June 30, 1871. Jul. 12, 1870. 41 ${ }^{\text {st }}$ Cong., $2^{\text {nd }}$ Sess., c. 251.16 Stat. 230 (1870).

An Act making Appropriations to supply Deficiencies in the Appropriations for the Execution of Reconstruction Acts, Ec.. Feb. 12, 1868. $40^{\text {th }}$ Cong., $2^{\text {nd }}$ Sess., c. 8.15 Stat. 35 (1868).

An Act making Appropriations to supply Deficiencies in the Appropriations for the Fiscal Year ending June 30, 1905, and for prior Years, and for other Purposes. Mar. 3, 1905. $58^{\text {th }}$ Cong., $3^{\text {rd }}$ Sess., c. 1484.33 Stat. 1214 (1905).

An Act making Appropriations to supply Urgent Deficiencies in the Appropriations for the Fiscal Year ending June 30, 1906, and for prior Years, and for other Purposes. Feb. 27, 1906. 59 $9^{\text {th }}$ Cong., $1^{\text {st }}$ Sess., c. 510.34 Stat. 27 (1906).

An Act to increase the Pay of the Privates in the Regular Army and in the Volunteers in the Service of the United States, and for other Purposes. Aug. 6, 1861. $37^{\text {th }}$ Cong., $1^{\text {st }}$ Sess., c. 63, § 3.12 Stat. 326 (1861).

Annual and Sick Leave Act of 1951. Pub. L. No. 82-233, Title II. 65 Stat. 679 (1951).

Budget Control Act of 2011. Pub. L. No. 112-25. 125 Stat. 240 (2011).

Budget Enforcement Act of 1990. Pub. L. No. 101-508, Title XIII. 104 Stat. 1388-573 (1990).

Congressional Budget and Impoundment Control Act of 1974. Pub. L. No. 93-344. 88 Stat. 297 (1974).

Consolidated Appropriations Act, 2005. Pub. L. No. 108-447. 118 Stat. 2809 (2005).

Continuing Appropriations Act, 2014. Pub. L. No. 113-46. 127 Stat. 558 (2013).

Federal Shutdown Response Emergency Act of 2013. D.C. Act No. 20-182 (2013).

First Continuing Resolution for FY 1996. Pub. L. No. 104-31. 109 Stat. 278 (1995).

Fourth Continuing Resolution for FY 1996. Pub. L. No. 104-94. 110 Stat. 25 (1996).

Further Continuing Resolution for FY 1996. Pub. L. No. 104-56. 109 Stat. 548 (1995).

General Appropriation Act, 1951. Sept. 6, 1950. 81 ${ }^{\text {st }}$ Cong., $2^{\text {nd }}$ Sess., c. 896.64 Stat. 595 (1950).

Gramm-Rudman-Hollings Balanced Budget and Emergency Deficit Control Act of 1985. Pub. L. No. 99-177, Title II. 99 Stat. 1038 (1985). 
Omnibus Budget Reconciliation Act of 1990. Pub. L. No. 101-508. 104 Stat. 1388 (1990).

Pay Our Military Act. Pub. L. No. 113-39. 127 Stat. 532 (2013).

Cases

Armster v. United States District Court, 792 F.2d 1423 (9 $9^{\text {th }}$ Cir. 1986)

Ex parte Garland, 71 U.S. (4 Wall.) 333, 18 L.Ed. 366 (1866)

Flemming v. Nestor, 363 U.S. 603, 80 S.Ct. 1367, 4 L.Ed.2d 1435 (1960)

Glavey v. United States, 182 U.S. 595, 21 S.Ct. 891, 45 L.Ed. 1247 (1901)

Glavey v. United States, 35 Ct. Cl. 242 (1900), rev'd on other grounds, 182 U.S. 595 (1901)

Immigration and Naturalization Service v. Chadha, 462 U.S. 919, 103 S.Ct. 2764, 77 L.Ed.2d 317 (1983)

MacMath v. United States, 248 U.S. 151, 39 S.Ct. 31, 63 L.Ed. 177 (1918)

Plaut v. Spendthrift Farm, Inc, 514 U.S. 211, 115 S.Ct. 1447, 131 L.Ed.2d 328 (1995)

Public Citizen v. Department of Justice, 491 U.S. 440, 109 S.Ct. 2558, 105 L.Ed.2d 377 (1989)

Saltzman v. United States, 161 Ct. Cl. 634 (1963)

Schick v. Reed, 419 U.S. 256, 95 S.Ct. 379, 42 L.Ed.2d 430 (1974)

United Automobile Workers v. Donovan, 746 F.2d 855 (D.C. Cir. 1984)

United States v. Grant, 237 F.2d 511 (7th Cir. 1956)

Youngstown Sheet E Tube Co. v. Sawyer, 343 U.S. 579, 72 S. Ct. 863, 96 L. Ed. 1153 (1952)

Administrative Decisions

Bureau of Land Management - Reimbursement of Contract Disputes Act Payments, 63 Comp. Gen. 308, B-211229 (GAO 1984)

Currency Exchange Rate Fluctuations, 58 Comp. Gen. 46, B-133316 (GAO 1978)

Department of Education: Recording of Obligations under the Guaranteed Student Loan Program, 65 Comp. Gen. 4, B-219161 (GAO 1983)

In re LTV Aerospace Corporation, 55 Comp. Gen. 307, B-183851 (GAO 1975)

In re Newport News Shipbuilding Co., 55 Comp. Gen. 812, B-184830 (GAO 1976)

Settlement and Certification of Judgment Claims, 1 Comp. Gen. 540 (GAO 1922)

Tax on Property of the Government, 9 Comp. Dec. 181 (Comp. Treas. 1902)

Voluntary Services - Deputy Collector of Internal Revenue, 27 Comp. Dec. 131 (Comp. Treas. 1920)

Voluntary Services, 9 Comp. Dec. 182 (Comp. Treas. 1902)

Bills and Resolutions

Continuing Appropriations Act, 2014, H.R. 2775, 113 $3^{\text {th }}$ Cong., $1^{\text {st }}(2013)$

Continuing Resolution for FY 1996, H.J. Res. 115, 104 $4^{\text {th }}$ Cong., $1^{\text {st }}(1995)$

Continuing Resolution for FY 2014, H.J. Res. 59, 113 ${ }^{\text {th }}$ Cong., $1^{\text {st }}$ (2013)

Federal Employee Retroactive Pay Fairness Act, H.R. 3223, $113^{\text {th }}$ Cong., $1^{\text {st }}(2013)$ 